\title{
Gunshot injury to the penis in a patient with penile prosthesis: a case report
}

\author{
Penis protezli hastanın penisinde ateşli silah yaralanması: Olgu sunumu
}

\author{
Metin İshak ÖZTÜRK, Abdullah İLKTAÇ, Orhan KOCA, \\ Senad KALKAN, Cevdet KAYA, Muhammet İhsan KARAMAN
}

\begin{abstract}
Civilian penetrating injuries to the penis are quite rare. We present the case of a 48 -year-old man with prosthetic implant surgery who referred to the emergency department of our clinic with penetrating gunshot injury to the penis. The damaged implant was removed and the defect on the anterior urethra was repaired primarily. To the best of our knowledge, there is no such report in the literature regarding penile gunshot injury in a patient with penile prosthesis.
\end{abstract}

Key Words: Penile prosthesis; gunshot injury; penile trauma.
Sivil hayatta penise penetran ateşli silah yaralanmaları enderdir. Bu yazıda, acil servise penise penetran ateşli silah yaralanması ile başvuran ve daha önce penis protez implantasyonu yapılmış olan 48 yaşındaki erkek hasta sunuldu. Hasarlı implant çıkarıldı ve anterior üretradaki yaralanma primer olarak onarıldı. Bildiğimiz kadarıyla bu yazıda, literatürde penis protezi olup penis ateşli silah yaralanması olan ilk hasta sunuldu.

Anahtar Sözcükler: Penis protezi; ateşli silah yaralanması; penis travmas1.
Although during periods of war, genital wounds account for a large percentage of urologic injuries (40$60 \%),{ }^{[1,2]}$ civilian penetrating injuries to the penis are quite rare ${ }^{[3]}$ probably due to its anatomical location. Patients with penile gunshot wounds commonly have associated injuries (in up to $80 \%$ of cases). Penile prosthesis implantation to correct irreversible erectile dysfunction is a common, well-established treatment, ${ }^{[4]}$ providing a suitable option for the surgical treatment of erectile dysfunction in men in whom conservative therapy fails. To our knowledge, there has been no previous report in the literature about penile gunshot injury in a patient with malleable penile prosthesis.

\section{CASE REPORT}

A 48-year-old male presented to the emergency department of our clinic with penetrating gunshot injury with a handgun to his penis. The patient was hemodynamically stable. The entrance wound of the bullet was on the right dorsolateral aspect and the exit wound was located on the right ventral aspect of the distal penile shaft. There were also entrance and exit wounds in the superior part of the scrotum and proximal onethird of the right thigh on the medial side. There was blood at the urethral meatus. Pelvic plain radiographs showed perforated right and intact left malleable penile prosthetic implant. Immediate retrograde urethrogram was performed, showing contrast medium extravasation from the anterior urethra. The patient had a history of malleable penile prosthetic implant surgery 12 years ago because of erectile dysfunction due to diabetes. During the physical examination, it was seen that the implant located on the right corpus was damaged. No testicular injury or active bleeding or hematoma was detected on the physical examination or ultrasound. A suprapubic catheter was placed and the patient was taken to surgery. Cefazolin $(1 \mathrm{~g})$, gentamicin $(80 \mathrm{mg})$ and metronidazole $(500 \mathrm{mg})$ was injected 1 hour before surgery for prophylaxis. After a circumferential incision, the penis was degloved and the right penile prosthesis was removed. There was an approximately $1 \mathrm{~cm}$ defect on the anterior urethra 


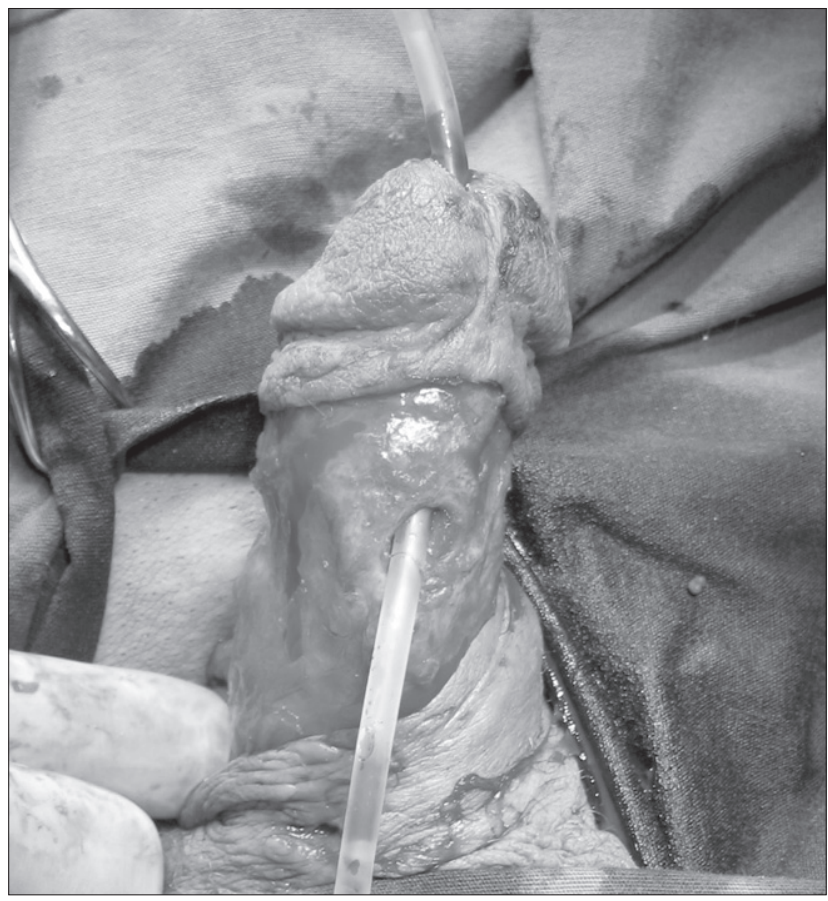

Fig. 1. Defect on the anterior urethra.

(Fig. 1). It was sutured with 4/0 Vicryl suture over an $18 \mathrm{~F}$ urethral catheter. The damaged part of the corpora cavernosa was repaired with $2 / 0$ Vicryl. The prosthesis was perforated by the bullet and inner metallic parts of the prosthesis had migrated to the scrotum (Fig. 2). During the surgery, the left penile prosthesis was checked manually and was determined to be functional and was thus retained in place.

Five days after surgery, the patient was discharged from the hospital. The Foley catheter was removed 14 days after surgery. The patient had spontaneous micturition. During the follow-up at six months, he was found to have no lower urinary tract symptoms. He had a Qmax of $19 \mathrm{ml} / \mathrm{sec}$. He was capable of performing sexual intercourse with the remaining prosthesis (International Index of Erectile Function [IIEF] score: 22 ).

\section{DISCUSSION}

The most important part of the evaluation of a patient with penetrating penile trauma is physical examination of the wound. The presence of active bleeding and/or hematoma, assessment of missile trajectory, recognition of blood at the meatus as well as search for other associated injuries are essential. ${ }^{[5]}$ Generally, urethrography is suggested for all patients with penetrating penile injury because up to $50 \%$ have urethral involvement. ${ }^{[6,7]}$ Incidence of urethral injury in patients with penile gunshot injury was reported as $33 \%$ in a series of 43 cases. ${ }^{[8]}$ Exploratory surgery has been recommended for all penetrating injuries of the external genitalia. ${ }^{[3]}$ Most patients with penile gun-

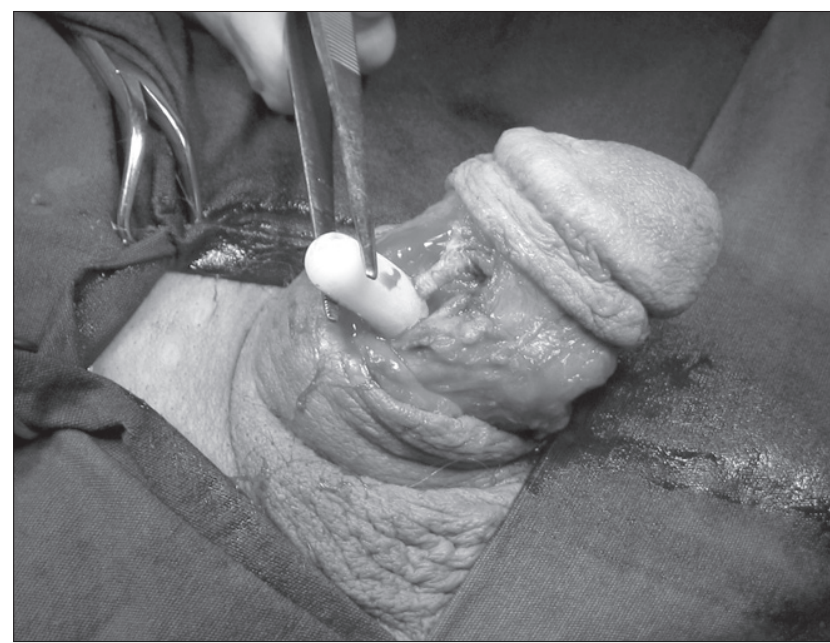

Fig. 2. Prosthesis perforated by the bullet.

shot injury require surgical debridement and closure. ${ }^{[9]}$ A minority of patients with minimal injury can be managed nonoperatively, representing approximately $10 \%$ of all patients, and all have superficial penetration or trivial penile injury. ${ }^{[6,7,10]}$ Management of associated anterior urethral injury has been controversial. ${ }^{[1]}$ Some authors suggest that patients with low velocity urethral gunshot wounds have excellent healing rates with suprapubic diversion alone, whereas others state that treatment of partial urethral disruption by primary repair over a Foley catheter has lower stricture rates than when primary repair was not attempted. ${ }^{[12,13]}$ The presence of a penile prosthesis complicated this case. To the best of our knowledge, there is no such report in the literature about penile gunshot injury in a patient with penile prosthesis. We removed the urethral catheter 14 days after surgery after which the patient had spontaneous micturition. In this case, no urethral stricture development or lower urinary tract symptom was present six months after surgery.

The corporal body injury was repaired primarily. We aimed to keep at least one prosthesis in place and, if necessary, to place an implant to the damaged part later. However, the patient indicated that he was satisfied with his sexual life with the remaining prosthesis and he did not want any additional treatment.

Results after gunshot injury to the penis are quite satisfactory, but careful assessment is essential. In gunshot injuries, the wound and pelvic radiographs should be examined carefully, as some pieces of the prosthesis may migrate to other parts of the pelvis. Retrograde urethrography should be performed in all patients except for selected cases. To our knowledge, there has been no other report in the literature about penile gunshot injury in a patient with penile prosthesis. In this case, removal of one prosthetic implant did not affect the sexual life of the patient. 


\section{REFERENCES}

1. Salvatierra O Jr, Rigdon WO, Norris DM, Brady TW. Vietnam experience with 252 urological war injuries. J Urol 1969;101:615-20.

2. Selikowitz SM. Penetrating high-velocity genitourinary injuries. Part II: Ureteral, lower tract, and genital wounds. Urology 1977;9:493-9.

3. Phonsombat S, Master VA, McAnnich JW. Penetrating external genital trauma: a 30-year single institution experience. J Urol 2008;180:192-6.

4. Garber BB. Inflatable penile prostheses for the treatment of erectile dysfunction: an update. Expert Rev Med Devices 2008;5:133-44.

5. Goldman HB, Dmochowski RR, Cox CE. Penetrating trauma to the penis: functional results. J Urol 1996;155:551-3.

6. Jankowski JT, Spirnak JP. Current recommendations for imaging in the management of urologic traumas. Urol Clin North Am 2006;33:365-76.

7. Cline KJ, Mata JA, Venable DD, Eastham JA. Penetrating trauma to the male external genitalia. J Trauma 1998;44:492-4.
8. Cavalcanti AG, Krambeck R, Araujo A, Manes CH, Favorito LA. Penile lesion from gunshot wound: a 43-case experience. Int Braz J Urol 2006;32:56-63.

9. Bandi G, Santucci RA. Controversies in the management of male external genitourinary trauma. J Trauma 2004;56:136270.

10. Morey AF, Rozanski TA. Genital and lower urinary tract trauma. In: Wein AJ, Kavoussi LR, Novick AC, Partin AW, Peters CA, editors. Campbell's urology. Vol 3, 9th ed., Philadelphia: W.B. Saunders Co.; 2007. p. 2649-62.

11. Brandes SB, Buckman RF, Chelsky MJ, Hanno PM. External genitalia gunshot wounds: a ten-year experience with fiftysix cases. J Trauma 1995;39:266-72.

12. Pontes JE, Pierce JM Jr. Anterior urethral injuries: four years of experience at the Detroit General Hospital. J Urol 1978;120:563-4.

13. Husmann DA, Boone TB, Wilson WT. Management of low velocity gunshot wounds to the anterior urethra: the role of primary repair versus urinary diversion alone. J Urol 1993;150:70-2. 